\title{
EMPLOYEE HANDBOOKS \\ AND \\ EMPLOYMENT-AT-WILL CONTRACTS
}

\section{INTRODUCTION}

Employees commonly receive from their employers an "employee handbook." That document is frequently an elaborate expression of the employer's personnel policies. An employee handbook typically informs the employee about grievance and termination procedures, severance pay, insurance, vacation pay, and general operating rules. However, if the employee happens to be one of the two out of three American workers who is hired on an at-will basis ${ }^{1}$ and thus can quit or be fired for any or no reason, it is also common for that employee not to receive the benefit of the promises fonnd in the employee handbook.

This note examines whether employee handbooks can be considered part of an at-will employment contract, thus binding the employer to the provisions of his personnel manual. ${ }^{2}$ After a brief discussion of the traditional employment-at-will doctrine, ${ }^{3}$ this note describes the contract

1. An employment contract can be terminable at will im one of two ways. First, it may be expressly stated in the contract that the employment is termimable at will. Second, and more prevalent, the term of the employment may not be specified, thus imvoking the employment-at-will doctrine. Note, Limiting the Right to Terminate at Will-Have the Courts Forgotten the Employer?, 35 VAND. L. REV. 201, 201 (1982) [heremafter cited as Note, Limiting the Right to Terminate at Will].

The enployment-at-will doctrime in America provides that a hiring which is for an indefinite term is an employment-at-will and may be terminated by either party at any time, with or without cause. DeGiuseppe, The Effect of the Employment-At-Will Rule on Employee Rights to Job Security and Fringe Benefits, 10 FORDHAM URB. L.J. 1, 8 (1981).

Approximately $60 \%$ to $65 \%$ of all American employees are employees at-will. Note, Protecting At Will Employees Against Wrongful Discharge: The Duty to Terminate Only in Good Faith, 93 HaRV. L. REv. 1816, 1816 n.2 (1980) [hereinafter cited as Note, Protecting At Will Employees]. For a detailed history of the doctrine of employment-at-will, sec Feimman, The Development of the Employment At Will Rule, 20 AM. J. LEGAL HisT. 118, 119-29 (1976); Note, Job Security for the At Will Employee: Contractual Right of Discharge for Cause, 57 CHI.[-]KENT L. REv. 697, 699-711 (1981) [heremafter cited as Note, Job Security]; Note, Implied Contract Rights to Job Security, 26 STAN. L. REv. 335, 340-47 (1974) [heremafter cited as Note, Implied Contract Rights].

2. The scope of this note is limited to contract analysis. Arguments based on tort, public policy, or statute will not be considered.

For a practical employee dismissal manual that is both recent and comprehensive, see H. PERRITT, EMPLOYEe Dismissal LAW AND PRACTICE (1984).

3. See infra notes 9-21 and accompanying text. 
analysis typically applied to employee handbooks which results in the employer not being bound to his promises. ${ }^{4}$ However, the prevailing judicial attitude is fast changing. The note describes the struggle with basic contract concepts experienced by courts undergoing cliange, as exemplified by one jurisdiction, 5 and tlien examines low some progressive courts have refused to treat liandbooks as hollow promises and instead have lield employee liandbooks to be contractually binding. ${ }^{6}$ Finally, this note argues that most courts, whether or not they have found employee handbooks to be part of employment-at-will contracts, liave used contract analysis that is, at best, superficial. ${ }^{7}$ It then urges all courts to apply unilateral contract analysis to employee handbook cases. ${ }^{8}$

\section{BACKground: The EMPloyment-AT-Will Doctrine}

Tlie enıployer-employee relationship is the product of an agreenient between the employer and eniployee regarding the nature of the work to be performed and various terms and conditions of employnent. As such, it is contractual in nature. 9 And it lias long been a major tenet of America's common law of contracts that an eniployment relationship, even tlougli terminable at will, is nevertheless contractual as well.10

The general rule that an employee "at will" may be terminated for any reason is expressed im the often-quoted passage:

[M]en must be left, without interference to buy and sell where they please, and to discharge or retain employees at will for good cause or for no cause, or even for bad cause without thereby being guilty of an unlawful act per se. It is a right which an employee inay exercise in the same way, to the same extent, for the same cause or want of cause as the einployer. ${ }^{11}$

4. See infra notes $22-46$ and accompanying text.

5. See infra notes $47-72$ and accompanying text.

6. See infra notes 73-93 and accompanying text.

7. See infra text accompanying notes 94-96.

8. See infra text accompanying notes 97-125.

9. Hainby v. Genesco, Inc., 627 S.W.2d 373, 375 (Tenn. Ct. App. 1981) (citing 53 AM. JUR. 2d Master and Servant $\S 14$ (1970)); W. OUTTEN, The Rights of EMPloyees 3 (1983); see 9 S. Williston, A TREatise on the LAW of Contracts $\S 1012$ (W. Jaeger 3d ed. 1967).

10. See 9 S. Williston, supra note $9, \S 1017 ; 3$ A A. Corbin, Corbin on Contracts $\S 684$ (1960 \& Supp. 1971); see also Comment, Employment At Will and the Law of Contracts, 23 Buffalo L. REV. 211, 212-16 (1973).

11. Payne v. Western \& Atl. R.R., 81 Tenn. 507, 518-19 (1884), overruled on other grounds, Hutton v. Watters, 132 Tenn. 527, 544, 179 S.W. 134, 138 (1915); see also National Protective Ass'n of Stream Fitters v. Cumming, 170 N.Y. 315, 63 N.E. 369 (1902). The Cumming court captured the individualism that came to characterize the employment-at-will doctrine:

It is not the duty of one man to work for another unless he has agreed to, and if he has so agreed but for no fixed period, either may end the contract whenever he chooses. The one may work or refuse to work at will, and the other may hire or discharge at will. The terins of employment are subjeet to mutual agreement, without let or hindrance from anyone. If 
The notion of freedom of contract 12 was the basis for the common law presumption that because each party was free to contract for a specific term-that is, the length of employment-the absence of that specific term in the employment contract indicated a mutual desire of the parties to retain the freedom to end their contract at any time. ${ }^{13}$

The employment-at-will doctrime has been beneficial to the employer because he can inore easily tailor his work force to the exigencies of any business situation and he can easily remove any employee who is unproductive or incoinpatible with the employer. ${ }^{14}$ Similarly, courts have recognized the doctrine's beneficial effect on the free enterprise system. ${ }^{15}$

The doctrine, however, has had harsh effects on employees. ${ }^{16}$ It has long been the rule that in the absence of a fixed-term contract, unlawful discrimination, or a specific constitutional right, a discharged employee

the terms do not suit, or the employer does not please, the right to quit is absolute, and no one may demand a reason therefor.

Cumming, 170 N.Y. at 320-21, 63 N.E. at 369.

For modern expressions of the employment-at-will doctrine, see, for example, Bender Ship Repair, Inc. v. Stevens, 379 So. 2d 594, 595 (Ala. 1980) (employment contract could be terminated by either party with or without cause or justification); Jones v. Keogh, 137 Vt. 562, 564, 409 A.2d 581, 582 (1979) (employee is without remedy even if malice, retaliation, or bad faith were reasons for discharge).

12. See M. Witmark \& Sons v. Fred Fisher Music Co., 125 F.2d 949, 962 (2d Cir. 1942) (Frank, J., dissenting), aff'd, 318 U.S. 643 (1943) ("[M]en should have the greatest possible liberty to make such contracts as they please.").

13. Note, Reforming At-Will Employment Law: A Model Statute, 16 U. M1CH. J.L. REF. 389, 391 (1983).

14. Comment, supra note 10 , at 240.

15. See, e.g., Whittaker v. Care-More, Inc., 621 S.W.2d 395 (Tenn. Ct. App. 1981). The Whittaker court wrote:

[B]ased upon our review of this area of the law we are compelled to note that any substantial change in the "employment-at-will" rule should first be microscopically analyzed regarding its effect on the commerce of this state. There must be protection from substantial impairment of the very legitimate interests of an employer in hiring and retaining the most qualified personnel available or the very foundation of the free enterprise system could be jeopardized.

Id., at 396.

16. See, e.g., Loucks v. Star City Glass Co., 551 F.2d 745 (7th Cir. 1977) (einployee-at-will dismissed in retaliation for filing workmen's compensation claim); Hablas v. Armour \& Co., 270 F.2d 71 (8th Cir. 1959) (employee-at-will discharged after 45 years of satisfactory performance when he was only one year away from retirement); Ivy v. Army Times Publishing Co., 428 A.2d 831 (D.C. 1981) (employee-at-will who testified at an adninistrative hearing at his employer's behest was fired for revealing evidence under oath that proved damaging to employer); Martin v. Platt, 179 Ind. App. 688, 386 N.E.2d 1026 (Ind. Ct. App. 1979) (employees-at-will dismissed for reporting employer kickbacks); Bell v. Faulkner, 75 S.W.2d 612 (Mo. Ct. App. 1934) (einployee-at-will disinissed for refusing to vote for a pohtical candidate supported by employer); Fletcher v. Greiner, 106 Misc. 2d 564, 435 N.Y.S.2d 1005 (N.Y. Sup. Ct. 1980) (einployee-at-will dismissed for refusing to continue sexual relationship with employer); Geary v. Umited States Steel Corp., 456 Pa. 171, 319 A.2d 174 (1974) (employec-at-will fired after voicing concern over the safety of a product inanufactured by his employer). 
has no recourse against his or her employer. ${ }^{17}$

Partly in recognition of the doctrine's unfairness to employees, inany commentators have criticized the doctrine ${ }^{18}$ and the courts have eroded it. ${ }^{19}$ As of 1983, twenty-nine states had granted some form of common law exception to the at-will doctrine. Five other states, as well as the District of Columbia, have imdicated their willingness to do so.20

17. Brooks v. Trans World Airlines, Inc., 574 F. Supp. 805, 808 (D. Colo. 1983) (citing Justice v. Stanley Aviation Corp., 35 Colo. App. 1, 4, 530 P.2d 984, 985 (1974); Amaan v. City of Eureka, 615 S.W.2d 414, 415 (Mo.), cert. denied, 454 U.S. 1084 (1981); Johnson v. National Beef Packing Co., 220 Kan. 52, 54, 551 P.2d 779, 781 (1976); Lynas v. Maxwell Farms, 279 Mich. 684, 687, 273 N.W. 315, 316 (1937); Knudsen v. Green, 116 Fla. 47, 52, 156 So. 240, 242 (1934); Martin v. New York Life Ins. Co., 148 N.Y. 117, 121, 42 N.E. 416, 417 (1895)).

18. See, e.g., Bellace, A Right of Fair Dismissal: Enforcing a Statutory Guarantee, 16 U. MicH. J.L. REF. 207 (1983); Blades, Employment at Will vs. Individual Freedom: On Limiting the Abusive Exercise of Employer Power, 67 Colum. L. REv. 1404 (1967); DeGiuseppe, supra note 1; Malin, Protecting the Whistleblower From Retaliatory Discharge, 16 U. MICH. J.L. REF. 277 (1983); Peck, Unjust Discharges From Employment: A Necessary Change in the Law, 40 OH1o ST. L.J. 1 (1979); Stieber \& Murray, Protection Against Unjust Discharge: The Need for a Federal Statute, 16 U. MicH. J.L. REF. 319 (1983); Summers, Individual Protection Against Unjust Dismissal: Time for a Statute, 62 VA. L. ReV. 481 (1976); Weyand, Present Status of Individual Employee Rights, N.Y.U. 22d ANNuAl Conference on LABor 171 (1970); Note, Job Security, supra note 1; Note, Continued Resistance to the Inclusion of Personnel Policies in Contracts of Employment: Griffin v. Housing Authority of Durham, 62 N.C.L. REV. 1326 (1984); Note, Implied Contract Rights, supra note 1; Note, Challenging the Employment-At-Will Doctrine Through Modern Contract Theory, $16 \mathrm{U}$. MicH. J.L. REF. 449 (1983) [hereinafter cited as Note, Challenging the Employment-At-Will Doctrine]; Note, The Employment-At-Will Doctrine: Providing a Public Policy Exception to Improve Worker Safety, 16 U. MiCH. J.L. REF. 435 (1983); Note, supra note 13; Note, Employment at Will: Emerging Protections for the Employee, 22 WASHBuRn L.J. 491 (1983); Comment, The At-Will Doctrine: $A$ Proposal to Modify the Texas Employment Relationship, 36 BAYLOR L. REV. 667 (1984). But see Heinz, The Assault on the Employment at Will Doctrine: Management Considerations, 48 Mo. L. REv. 855 (1983); Petrikin, In Defense of Employment at Will, 53 OKLA. B.J. 2209 (1982); Note, Limiting the Right to Terminate at Will, supra note 1.

For an extensive bibliography of the einployment-at-will doctrine, see The Employment-At-Will Issue, LAB. REL. REP. (BNA) (Special Report) Vol. III, No. 23, at $81-85$ (Nov. 22, 1982) [hereinafter cited as The Employment-At-Will Issue].

19. E.g., Tameny v. Atlantic Richfield Co., 27 Cal. 3d 167, 164 Cal. Rptr. 839, 610 P.2d 1330 (1980) (recognizing tort action for wrongful discharge in violation of public pohicy); Cleary v. American Airlines, Inc., 111 Cal. App. 3d 443, 168 Cal. Rptr. 722 (1980) (recognizing a covenant of good faith in employinent contracts).

20. Novosel v. Nationwide Ins. Co., 721 F.2d 894, 896 (3d Cir. 1983). Coinmon law exceptions to the employment-at-will rule have allowed recovery in recent years under tort and implied contract theories for the wrongfully discharged employee. DeGiuseppe, supra note 1, at 23. The tort theory of recovery provides what is often called "public policy exceptions" to the employment at will doctrine. Courts have granted relief to einployees discharged for refusing to violate a criminal statute, exercising a statutory right, fulfilling a statutory duty, and other violations of general public policy. Note, Limiting the Right to Terminate at Will, supra note 1, at 204. Implied contract thcory has been used to find that a discliarge constitutes a breach of the "implied covenant of good faitl and fair dealing." DeGiuseppe, supra note 1, at 23-24. For a state-by-state survey and analysis of the exceptions, see A.B.A. LITIGATION SECTION, EMPLOYMENT AND LABOR RELATIONS LAW COMMITTEE, EMPLOYMENT-AT-WILl: A STATE-By-STATE SuRVEY, 1984 REPORT OF THE EMPLOYMENT-ATWILL SUBCOMMITTEE, and The Employment-At-Will Issue, supra note 18, at 8, 33-65. 

Policy statements im a personnel manual are usually considered umlateral statements by the employer and thus subject to unilateral amendment by him. Most courts, ${ }^{24}$ and some commentators, ${ }^{25}$ find it liard to imagine that promises found in an employee handbook that can be unilaterally amended could also be contractually binding. Even employer pronises that confer benefit to the einployer, such as employee loyalty, are mere gratuities witl no contractual status. ${ }^{26}$

In the absence of consideration independent froin performance of the job by the employee, or inutual bargaining between the employer and employee, most courts have found handbooks to be unilateral statements by the einployer and hence unenforceable. ${ }^{27}$ In order to make provisions

Auth. of Durham, 62 N.C. App. 556, 557, 303 S.E.2d 200, 201 (1983); Williams v. Biscuitville, Inc., 40 N.C. App. 405, 408, 253 S.E.2d 18, 20, cert. denied, 297 N.C. 457, 256 S.E.2d 810 (1979); Richardson v. Charles Cole Memorial Hosp., 320 Pa. Super. 106, 108-09, 466 A.2d 1084, 1085 (1983); Reynolds Mfg. Co. v. Mendoza, 644 S.W.2d 536, 539 (Tex. Civ. App. 1982); Parker v. United Airlines, Inc., 32 Wash. App. 722, 726-27, 649 P.2d 181, 183-84 (1982); Ferraro v. Koelsch, 119 Wis. 2d 407, 412-13, 350 N.W.2d 735, 738 (Wis. Ct. App.), petition for review granted, 119 Wis. 2d 903, 353 N.W.2d 808 (Wis. 1984); Holloway v. K-Mart Corp., 113 Wis. 2d 143, 146, 334 N.W.2d 570, 572 (Wis. Ct. App. 1983).

24. E.g., Johnson v. National Beef Packing Co., 220 Kan. 52, 55, 551 P.2d 779, 782 (1976) (manual is a unilateral expression of conipany policy the terms of which were not bargained for).

25. E.g., Brody, Labor Law: Deciphering the Word From Delphi, 58 CHI.[-] KENT L. REv. 439, $475 \mathrm{n} .131$ (1982) (when policy statements are subject to unilateral amendment by the employer, it is difficult to understand how there can be a meeting of the minds).

26. See id. ("[T]he mere fact that the employer derives some ultimate benefit from [proumises in a policy manual] does not differentiate them fronı nıost other gratuities.").

27. E.g., Caster v. Heimessey, 727 F.2d 1075 (11th Cir. 1984) (grievance procedure set out in nianual was neither bargained for nor inutually agrced upon); Mau v. Omaha Nat'l Bank, 207 Neb. 308, 314, 299 N.W.2d 147, 151 (1980) (manual does not bind employer). See also Note, Challenging the Employment-At-Will Doctrine, supra note 18, at 458 n.63 (citimg Shaw v. S.S. Kresge Co., 167 Ind. App. 1, 328 N.E.2d 775 (1975); Johnson v. National Beef Packing Co., 220 Kan. 52, 551 P.2d 779 (1976); Gates v. Life of Mont. Ins. Co., 196 Mont. 178, 638 P.2d 1063 (1982) (dictum); Weiner v. McGraw-Hill, Inc., 57 N.Y.2d 458, 443 N.E.2d 441, 457 N.Y.S.2d 193 (1982)).

The requirement of consideration is the most fundanental himitation on the enforcenent of promises. E. FARNSwORTH, CONTRACTS $\$ 2.2$ (1982). Consideration is the inducement to contract that must exist if a court is to enforce a promise as a contract. Simply stated, consideration is "a detriment incurred by the promisee or a benefit received by the promisor at the request of the promisor." S. WILLISTON, supra note $9, \S 102$. A recent trend is to describe the requirement of consideration in terms of a bargained-for exchange rather than in terms of a search for either benefit or detriment. E. FARNSwORTH, supra. "The essence of consideration . . . is legal detriment that has been bargained for and exchanged for the promise." J. CALAMARI \& J. PERILLO, THE LAW OF CONTRACTs $\$ 4-1$ (2d ed. 1977) (footnote oinitted).

In the employment context, an employee's labor and services traditionally were viewed as consideration for the salary paid by the employer. If the employee wanted the employer to be bound by other promises, additional consideration was necessary. See Note, Implied Contract Rights, supra note 1, at 351-52. For exanple, at the turn of the century, courts enforced oral proinises of permanent employment made to injured railroad employees in exchange for their executed written releases from tort claims against the employer. The imjured employee's surrender of the tort claims was separate consideration and justified the enforcement of the contract for permanent employment. Id. at $352-53$. 
of a handbook contractually binding, soinething inore than just the performance of duties on the part of the employee and the payinent of wages on the part of the employer is needed. ${ }^{28}$ It is solnetimes said that a handbook is not a contract because there is no "mutuality of obligation."29 Why should an employer be bound by promises in the manual when the employee is free to terminate his employment at any time and for any or no reason? ${ }^{30}$

Courts have used such contract analysis regardless of whether the einployee handbook was pubhished and distributed before ${ }^{31}$ or after ${ }^{32}$ the plaintiff was hired. And finally, possibly in reaction to the call for change, courts have expressed reluctance to depart froin long-established primciples that require definiteness and certainty in the terms of employment contracts. ${ }^{33}$

In Johnson v. National Beef Packing Co., ${ }^{34}$ the Supreme Court of Kansas wrote: "[The Policy Manual] was only a umilateral expression of coinpany policy and procedures. Its terms were not bargained for by the

28. See Note, Implied Contract Rights, supra note 1, at $351-52$ (additional consideration is needed to make employment contracts of indefinite duration binding).

29. "Mutuality of obligation requires that unless both parties to a contract are bound, neither is bound." Sala \& Ruthe Realty, Inc. v. Campbell, 89 Nev. 483, 487, 515 P.2d 394, 396 (1973).

30. See, e.g., Edwards v. Citibank, N.A., 74 A.D.2d 553, 554, 425 N.Y.S.2d 327, $328-29$ (1980) (the manual "does not create an obligation on the part of the employer to contimue the employment of the employee for life, subject only to the conditions set forth in the manual while leaving the employee free to terminate his employment at any time and for any or no reason") (citations omitted).

31. E.g., Sargent v. Illinois Inst. of Teehnology, 78 Ill. App. 3d 117, 121-22, 397 N.E.2d 443, 446 (1979) (if the handbook is distributed at the time of hiring, there is no consideration and probably no reliance); Shaw v. S.S. Kresge Co., 167 Ind. App. 1, 4, 7, 328 N.E.2d 775, 777, 779 (1975) (employee was furnished a copy of the handbook when his employinent began and for want of mutuality of obligation or consideration, the handbook promises are not enforceable).

32. E.g., Caster v. Hennessey, 727 F.2d 1075, 1076-77 (11th Cir. 1984) (handbook given to employee 10 months after begiuning employment not binding on either party given that Florida law has not relaxed the requirements of definiteness in employment contracts); Grimes v. Shearson/ American Express, Inc., No. 83-C-6344 (N.D. Ill. July 12, 1984) (available Feb. 8, 1985, on LEXIS, Genfed hibrary, Dist file) ("It is particularly absurd for plaintiff to contend that this was a contract of employment when she did not receive a copy of the document until after she had begun working for the defendant, she was employed without any particular term of employment and not in reliance upon the document in question."); Johnson v. National Beef Packing Co., 220 Kan. 52, 54-55, 551 P.2d 779, 781-82 (1970) (there was no meeting of the minds or bargain for a policy manual that was published and distributed to employees nine or ten months after commencement of plaintiffs employment); Gates v. Life of Mont. Ins. Co., 196 Mont. 178, 183, 638 P.2d 1063, 1066 (1982) (if the handbook is written and distributed after employment is accepted, there is no consideration or reliance).

33. E.g., Muller v. Stromberg Carlson Corp., 427 So. 2d 266, 268 (Fla. Dist. Ct. App. 1983) ("An employee's entitlement to a particular term of employment or to particular salary levels on the basis of criteria more subject to misunderstanding and dispute than definite terms in an employment contract is not . . . the province of a court of law.").

34. 220 Kan. 52, 551 P.2d 779 (1976). 
parties and any benefits conferred by it were mere gratuities. Certainly no meeting of the minds was evidenced by the [einployer's] umilateral act of publishing coinpany policy."35 A simple expectation on the part of the einployee that, for example, good performance would be rewarded by yearly bonuses as stipulated in a bonus schedule or plan has been held imsufficient to create a binding term of the einployment contract. ${ }^{36}$ That is not surprising given the judicial attitude that since employers can typically unilaterally amend or withdraw the policies of liandbooks, it must follow that nothing in handbooks can contain any strict promissory language. ${ }^{37}$

In addition to citimg lack of consideration or want of mutuality as a bar to einployees' contract claims, courts have also held that even if the einployee liandbook constituted an employment contract, that contract would still be terminable at will because the handbook does not set forth all the terms of einployment, particularly a fixed term of employment. ${ }^{38}$ For example, in Chin v. American Telephone \& Telegraph Co., ${ }^{39}$ the court found that because the employer's code of conduct did not contain all the terms of the employee's einployment-that is, essential terms such

35. Id. at 55, $551 \mathrm{P} .2 \mathrm{~d}$ at 782 .

36. Muller v. Stromberg Carlson Corp., 427 So. 2d 266, 268 (Fla. Dist. Ct. App. 1983).

37. See, e.g., Wemer v. McGraw-Hill, Inc., 57 N.Y.2d 458, 468, 443 N.E.2d 441, 447, 457 N.Y.S.2d 193, 199 (1982) (Wachtler, J., dissenting) (one would not expect a manual to contain any strict promissory language given that the employer is free to amend or withdraw any provisions in the manual).

38. See, e.g., White v. Chelsea Indus., 425 So. 2 d 1090, 1090-91 (Ala. 1983) (even though a handbook exists, there has to be an agreement speeifying a definite duration of employment services or limiting the employer's legal right to terminate the employment; otherwise the relationship is atwill); Heideck v. Kent Gen. Hosp. Inc., 446 A.2d 1095, 1096-97 (Del. 1982) (an employee will find no relief where the inanual is merely a unilateral statement of company policies and where it does not set out a definite term of employment for company employees) (citing Beidler v. W.R. Grace, Inc., 461 F. Supp. 1013, 1016 (E.D. Pa. 1978), aff'd mem., 609 F.2d 500 (3d Cir. 1979); Terrio v. Millinocket Community Hosp., 379 A.2d 135, $137-38$ (Me. 1977); Johnson v. National Beef Packing Co., 220 Kan. 52, 54-55, 551 P.2d 779, 781-82 (1976); Dickhaus v. Jersey Cent. Power \& Light Co., No. A-3281-80-T2 (N.J. Super. Ct. App. Div. Nov. 13, 1981), cert. denied, 89 N.J. 430 (1982)); Shaw v. S.S. Kresge Co., 167 Ind. App. 1, 7, 328 N.E.2d 775, 779 (1975) ("Even assuming, arguendo, that the laandbook rehed upon by appellant constituted a part of the contract, in the absence of a promise on the part of the employer that the employment should continue for a period of time that is either definite or capable of determination, the employment relationship is terminable at the will of the employer."); Chin v. AT\&T, 96 Misc. 2d 1070, 1073, 410 N.Y.S.2d 737, 739 (Sup. Ct. 1978) (manual does not contain all the terms of employment and is thus terminable at will regardless of the regulations for termination found in the manual), aff'd mem, 70 A.D.2d 791, 416 N.Y.S.2d 160 (App. Div. 1979), appeal denied, 48 N.Y.2d 603, 396 N.E.2d 207, 421 N.Y.S.2d 1028 (1979).

39. 96 Misc. 2d 1070, 410 N.Y.S.2d 737 (Sup. Ct. 1978), aff'd mem., 70 A.D.2d 791, 416 N.Y.S.2d 160 (App. Div. 1979), appeal denied, 48 N.Y.2d 603, 396 N.E.2d 207, 421 N.Y.S.2d 1028 (1979). The plaintiff was a discharged employee who had rehed on a "Code of Conduct," issued to the employee as a guide to the employer's regulations, as establishing the basis of his employment contract (which was otherwise oral), and also establishing the only grounds upon which his employment could be terminated. Id. at 1072, 410 N.Y.S.2d at 739 . 
as the duties and responsibilities of the particular position, the length of employment, and compensation - the code of conduct could not provide the exclusive grounds for termination..$^{40}$

In short, courts have traditionally rejected the argument that the provisions of employee handbooks form a part of an at-will employment contract. They have done so by finding no independent-or "extra"consideration, ${ }^{41}$ no bargain or meeting of minds, ${ }^{42}$ no intent to create contractual rights, ${ }^{43}$ and no fixed term in the handbook. ${ }^{44}$ Finally, courts have also cited public policy concerns, such as business inefficiency and migration ${ }^{45}$ and employer retrenchment of beneficial employee policies, ${ }^{46}$ as reasons for not extending contractual status to employee handbooks.

40. Chin, 96 Misc. $2 \mathrm{~d}$ at 1073,410 N.Y.S.2d at 739.

41. See supra notes $27-30$ and accompanying text.

42. E.g., Lieber v. Union Carbide Corp., 577 F. Supp. 562, 564 (E.D. Tenn. 1983) (there must be a meeting of the minds by the parties that the handbook's provisions conferred a contractual right on the employee). See supra notes 34-35 and accompanying text.

43. E.g., Lieber v. Uniou Carbide Corp., 577 F. Supp. 562, 564 (E.D. Tenn. 1983) (employer did not intend to create an employee benefit and no such right was created).

44. See supra notes 38-40 and accompanying text. The traditional contract analysis is perhaps best exemplified by Edwards v. Citibank, N.A., 100 Misc. 2d 59, 418 N.Y.S.2d 269 (Sup. Ct. 1979), aff'd, 74 A.D.2d 553, 425 N.Y.S.2d 327 (1980). Edwards brought an action for breach of contract and wrongful discharge against his former employer, a bank, claiming he was wrongfully discharged in reprisal for having uncovered evidence of illegal foreign currency manipulation. Id. at 59, 418 N.Y.S.2d at 270. For the six years he was employed by the bank, the plaintiff had no formal written contract and no fixed term of employment. Id. at 60,418 N.Y.S.2d at 270 . The plaintiff contended not only that various staff handbooks and manuals comprised a written contract, but also that the effect of those documents, which included other literature setting out broad employment policy guidelines, was to give him a permanent position that was unlimited in duration. The plaintiff claimed that although the contract was terminable by hin at will, the bank could only terminate him for canse. Id. The court dismissed the plaintiff's contention that the handbook constituted a contract for three reasons:

First, it is utterly lacking in mutuality. Second, it is hornbook law that any contract for an indefinite period of time is terminable at the will of either party at any timc. Such a contract is terminable "for any reason or for no reason." Third, the various manuals offered by plaintiff do not constitute a written employment contract, since they do not exclusively and completely define the terms and conditions of employment, its duration or the rate of compensation, i.e., all the essential elements of a contract of employment.

Id. (citations omitted). For those reasons, the court found that the employer's policy docunients were "no more than broad internal policy gnidelines which cannot be held to embody the exclusive procedures for termination." Id.

45. Weiner v. McGraw-Hill, Inc., 57 N.Y.2d 458, 468-69, 443 N.E.2d 441, 447, 457 N.Y.S.2d 193, 199 (1982) (dissent); Whittaker v. Care-More, Inc., 621 S.W.2d 395, 396-97 (Tenn. Ct. App. 1981).

46. Southwest Gas Corp. v. Ahmad, 99 Nev. 594, 601, 668 P.2d 261, 265 (1983) (dissent). 


\section{Contractual ANalysis of Employee Handbooks IN TRANSITION}

The judicial treatment of employee handbooks is in transition. The requirements of independent consideration, bargain, and the like are receiving increasing criticism. ${ }^{47}$ Consequently, in more and more jurisdictions, employee handbooks are found to contain enforceable contract rights. ${ }^{48}$ However, courts continue to struggle with the idea of the necessity of imdependent consideration, particularly as it relates to employees who are given a copy of an employee handbook when they begin employinent, as opposed to those who receive a handbook after they have been on the job for some time.

The transition in American courts is neatly reflected in Illinois, a state that is a paradigin of the struggle with the contractual treatment of einployee handbooks. The status of Illinois law concerning whether employee handbooks are a part of an employment contract is well-illustrated by three cases. ${ }^{49}$ What emerges froin the three cases is the general rule that employee handbooks are not contractually binding, but with two notable exceptions. The cases give a flavor of the variety of fact situations generally facing American courts today. The way Illinois courts have distinginished these various fact situations reveals the appre-

47. See infra notes 73-93, and accompanying text.

48. See, e.g., Vmyard v. King, 728 F.2d 428, 432-33 (10th Cir. 1984); Greene v. Howard Univ., 412 F.2d 1128, 1135 (D.C. Cir. 1969); Gorrill v. Icelandair/Flugleidir, No. 80 Civ. 5577 (RLC) (S.D.N.Y. May 14, 1984) (available Feb. 9, 1985, on LEXIS, Genfed hibrary, Dist file); Brooks v. Trans World Airlmes, Inc., 574 F. Supp. 805, 810 (D. Colo. 1983); Leikvold v. Valley View Community Hosp., _ Ariz. — 688 P.2d 170, 174 (1984) (en banc); Pugh v. See's Candies, Inc., 116 Cal. App. 3d 311, 329, 171 Cal. Rptr. 917, 927 (1981); Cleary v. American Airlines, Inc., 111 Cal. App. 3d 443, 455-56, 168 Cal. Rptr. 722, 729 (1980); Salimi v. Farmers Ins. Group, 684 P.2d 264, 265 (Colo. Ct. App. 1984); Piper v. Board of Trustees, 99 Ill. App. 3d 752, 760, 426 N.E.2d 262, 267 (1981); Carter v. Kaskaskia Community Action Agency, 24 Ill. App. 3d 1056, 1059, 322 N.E.2d 574, 576-77 (1974); Jackson v. Minidoka Irrigation Dist., 98 Idaho 330, 334, 563 P.2d 54, 58 (1977); Dahl v. Brunswick Corp., 227 Md. 471, 476, 356 A.2d 221, 224-25 (1976); Toussaint v. Blue Cross \& Blue Shield, 408 Mich. 579, 598-99, 292 N.w.2d 880, 885 (1980); Pime River State Bank v. Mettille, 333 N.W.2d 622, 629-30 (Minn. 1983); Lewis v. Equitable Life Assurance Soc'y, No. C8-84-1065 (Minn. Ct. App. Jan. 22, 1985) (available Feb. 9, 1985, on LEXIS, states hibrary, Minn file); Hoemberg v. Watco Publishers, Inc., 343 N.W.2d 676, 678 (Mim. Ct. App. 1984); Southwest Gas Corp. v. Ahmad, 99 Nev. 594, 595, 668 P.2d 261, 261 (1983); Forrester v. Parker, 93 N.M. 781, 782, 606 P.2d 191, 192 (1980); Hillis v. Meister, 82 N.M. 474, 477, 483 P.2d 1314, 1317 (N.M. Ct. App. 1971); Weiner v. McGraw-Hill, Inc., 57 N.Y.2d 458, 465-66, 443 N.E.2d 441, 445-46, 457 N.Y.S.2d 193, 197-98 (1982); Saunders v. Big Bros., Inc., 115 Misc. 2d 845, 847, 454 N.Y.S.2d 787, 790 (N.Y. City Civ. Ct. 1982); Langdon v. Saga Corp., 569 P.2d 524, 528 (Okla. Ct. App. 1976); Banas v. Matthews Int'1 Corp., No. 1205 Pittsburgh (Pa. Super. Ct. June 15, 1984) (available Feb. 8, 1985, on LEXIS, states hibrary, Pa file); Thompson v. St. Regis Paper Co., 102 Wash. 2d 219, _, 685 P.2d 1081,1087 (1984) (en banc).

49. Piper v. Board of Trustees, 99 Ill. App. 3d 752, 426 N.E.2d 262 (1981); Sargent v. Illinois Inst. of Technology, 78 Ill. App. 3d 117, 397 N.E.2d 443 (1979); Carter v. Kaskaskia Community Action Agency, 24 Ill. App. 3d 1056, 322 N.E.2d 574 (1974). 
hension of a jurisdiction in transition wholly to abandon the traditional contract analysis.

The first Illinois case to discuss the contractual status of employee handbooks was Carter v. Kaskaskia Community Action Agency. ${ }^{\text {so }}$ In Carter, the employee had no written employment contract, and there was no evidence of any oral contract governing the duration of his employment. Four years after the employee began work, the employer compiled and adopted a personnel manual which was reviewed and accepted by the employees and approved by the employer's board of directors. ${ }^{51}$ The manual contained procedures for grievances and disciplinary actions including dismissal. The employee argued that when his employer adopted the manual, it became a contract binding on both parties and he was thus illegally discharged because the manual's discharge procedures were not followed.52 The Carter court held that the employee was illegally discharged. ${ }^{53}$ According to the court, the manual was a modification of the existing at-will employinent contract-the manual was reviewed and accepted by the employees and later it was approved by the employer's board of directors. ${ }^{54}$ The court found mutuality of obligation from provisions in the manual that required employees to give thirty days' notice before resigning or lose their right to vacation pay, and required the employer to give employees certain grievance procedures. ${ }^{55}$ The court went on to explain that the fact that the employee continued to work after the modification of the contract also constituted assent to and consideration for the modification creating the mutuality of obligation necessary to bind both parties. 56

Thus, Carter stands for the proposition that an employee handbook that is adopted after an employee is hired at will becomes part of the preexistimg employment contract if it is a modification of the contractentailing a process of employee review and acceptance-and the handbook is bargained for or given imdependent consideration in the form of the employee's contmuing to work after the handbook takes effect. ${ }^{57}$

In the second Illinois case, Sargent v. Illinois Institute of Technol-

50. 24 Ill. App. 3d 1056, 322 N.E.2d 574 (1974).

51. The court did not specify the mode of employee review and acceptance. Id. at 1058, 322 N.E.2d at 576.

52. Id. at $1057-59,322$ N.E.2d at 575-76.

53. Id. at 1058,322 N.E.2d at 575 .

54. Id. at 1058,322 N.E.2d at 576.

55. Id. at 1059,322 N.E.2d at 576.

56. Id.

57. See Sargent v. Illinois Inst. of Technology, 78 Ill. App. 3d 117, 121-22, 397 N.E.2d 443, 446 (1979) (discussing Carter). 
$08 y,{ }^{58}$ there was no written contract; the employment was at-will. The plaintiff, who was discharged, contended that the terms of the personnel manual adopted and issued by the employer to its employees became an einployment contract and entitled him to the predischarge hearing prescribed in the manual. ${ }^{59}$ The Sargent court distimguished Carter by noting that (1) the guidelines set forth in the personnel manual were not a modification of any preexisting employment relationship because the plaintiff was given the manual when he began his employment; (2) the terms set forth in the personnel manual were not bargained for; and (3) the plaintiff provided no independent consideration to support the predischarge hearing requirement. ${ }^{60}$ The manual was not an enforceable contract but inerely a "code for [plaintiff's] conduct." 61 Thus, Sargent reasoned, as did Carter, that an employee handbook is not part of an atwill employment contract unless the handbook is a modification of the contract, is bargained for, and supported by independent consideration. ${ }^{62}$

The third of the three Illinois cases addressing the contractual status of employee handbooks is Piper v. Board of Trustees, ${ }^{63}$ involving a written employment contract for a term of one year. ${ }^{64}$ The court im Piper held that the employee manual was imcorporated into the written contract which stated that the plaintiff's appointment was subject to the "bylaws, policies and regulations of the Board of Trustees." 65 The court distinguished Sargent by noting that in Sargent there was no "written contract, so it would be impossible to imcorporate by reference a personnel manual."66 Piper thus stands for the proposition that employee handbooks can be part of an employment contract when two conditions are met: (1) a written contract is executed by the employer and einployee; and (2) the written contract can be construed as subject to the "policies" of the employer. ${ }^{67}$

What einerges from Carter, Sargent, and Piper is a general rule, with two exceptions, that einployee handbooks are not part of an employment contract. Under the first exception, if the employee handbook is a modification of a preexisting contract and there is mutuality of obligation, then the employee handbook becomes a part of the employment con-

\footnotetext{
58. 78 Ill. App. 3d 117, 397 N.E.2d 443 (1979).

59. Id. at 118, 397 N.E.2d at 444 .

60. Id. at 121-22, 397 N.E.2d at 446 .

61. Id. at 122, 397 N.E.2d at 446.

62. See id. at 121-22, 397 N.E.2d at 446.

63. 99 Ill. App. 3d 752, 426 N.E.2d 262 (1981).

64. Id. at 756,426 N.E. $2 \mathrm{~d}$ at 265.

65. Id. at 755,426 N.E. $2 \mathrm{~d}$ at 264.

66. Id. (emphasis added).

67. Id.
} 
tract. ${ }^{68}$ The second exception states that when a written contract can be construed as subject to the policies of the employer, then the employee handbook is incorporated into the existing employment contract. ${ }^{69}$

The Illinois cases imply that if an employee were given a copy of a handbook and asked to review it before accepting employment, a process having some of the cliaracteristics of a "modification," his commencement of work would not constitute sufficient consideration or bargaining to inake the handbook binding. ${ }^{70}$ There seems to be no good justification for the distmetion tliat continumg to work after a new liandbook is approved by employees constitutes consideration, whereas commencing work after approving an existing liandbook does not constitute consideration. The same process of mutual agreennent occurs when an employee reviews and accepts the provisions of a liandbook before, after, or contemporaneously witli commencing his employment. In all tliese instances, the employee begins or continues to work fully aware that lis employer's personnel manual will, from that moment on, apply to him.

In addition, Illinois courts have suggested that personnel manuals are not incorporated into oral contracts whose terms explicitly state that tlie employer's pohicies or personnel manual are a part of an employment contract. ${ }^{71}$ It does not seem to make sense that sucli incorporation can take place wlien the contract is written but not when it is oral. Whiat is important is that an agreement exists and not that the agreement has been memorialized. 72

In sum, the Illinois experience demonstrates that courts, in light of the traditional approacli to bargain and consideration, are reluctant to

68. Carter, 24 III. App. 3d at 1059, 322 N.E.2d at 576.

69. Piper, 99 III. App. $3 d$ at 760,426 N.E.2d at 267 . The same analysis of the three Illinois cases has been adopted by the United States District Court for Northern Illinois. See Wogan v. Nissan Motor Corp., No. 84-C-6885 (N.D. III. Jan. 29, 1985) (available Feb. 25, 1985, on LEXIS, Genfed hibrary, Dist file); Enis v. Continental I1l. Nat'1 Bank \& Trust Co., 582 F. Supp. 876 (N.D. III. 1984); Rynar v. Ciba-Geigy Corp., 560 F. Supp. 619 (N.D. III. 1983).

70. See Enis v. Continental III. Nat'l Bank \& Trust Co., 582 F. Supp. 876, 879 (N.D. 111. 1984) (by accepting the handbook when commencing eniployment, the eniployee "nierely agreed to properly perform her required duties and nothing noore"); Sargent, $78 \mathrm{III}$. App. 3d at 122, 397 N.E.2d at 446 (by agreeing to be bound by the handbook he was given when he began his einployment, the eniployee "nierely agreed to properly perform his required duties and nothing inore"); Note, Contract Law: An Alternative to Tort Law as a Basis for Wrongful Discharge Actions in Illinois, 12 LoY. U. CHI. L.J. 861, 882 (1981) (In Illinois, "an enployee who accepts work from an employer who has already proinulgated a personnel policy is considered not to have bargained for that policy").

71. See Piper, 99 Ill. App. 3d at 760, 426 N.E.2d at 267. See also Rynar v. Ciba-Geigy Corp., 560 F. Supp. 619, 624 (N.D. Ill. 1983) (when the employnent contract is oral, the incorporation argunient of Piper is not available). Although in Piper the employnent was for a definite term, this should not affect any incorporation analysis for at-will enployees.

72. See J. Calamari \& J. Perillo, supra note 27 , $\$ 1-1$ (" [R]ules of law utilizing the concept 'contract' rarely refer to the writing itself. Usually, the reference is to the agreement; the writing being nerely a meniorial of the agreenent."). 
extend contractual status to all employee handbooks and that those that have tried to extend contractual status to some employee handbooks have found it difficult to reach a consistent treatment. The Illinois courts are a paradigm of what can happen when courts move, step by step, away from the traditional treatment of employee handbooks. The results are inconsistent, illogical, and ultimately unsatisfactory.

\section{The Progressive View of the Contractual Status of EMPLOYEE HANDBOOKS}

By its very definition, the employment contract that is terminable at will carries with it no mutually agreed-upon standard for the dissolution of the employment relationship. ${ }^{73}$ More progressive courts, ${ }^{74}$ however, have been willing to use the provisions of employee handbooks as a standard for the dissolution because they have refused to view handbooks as " "corporate illusions, "full of sound . . . signifying nothing." "75 This new approach to employee handbook cases has involved a full-scale attack on the notions of the necessity of independent consideration and mutuality of obligation and on the doctrine of employment-at-will itself. ${ }^{76}$

The leading case in the attack on the traditional approach is Toussaint v. Blue Cross \& Blue Shield, ${ }^{77}$ in which the Supreme Court of Michigan upheld a jury verdict for a plaintiff, an employee-at-will, who claimed he had been discharged without just cause in violation of his employer's personnel manual, which provided that employees would be terminated for just cause only, pursuant to certam procedures. ${ }^{78}$ The Toussaint court completely rejected the idea that the provisions of an employee handbook must be bargamed for:

We hold that employer statements of policy, such as the Blue Cross Supervisory Manual and Guidelines, can give rise to contractual

73. Petrikin, supra note 18 , at 2212.

74. For lack of a better term, "progressive courts" describes those courts that have rejected outright the contract analysis traditionally used by courts addressing employee handbook cases. See infra notes 75-93 and accompanying text.

75. Weiner v. McGraw-Hill, Inc., 57 N.Y.2d 458, 462, 443 N.E.2d 441, 443, 457 N.Y.S.2d 193, 195 (1982) (Kupferman, J., dissenting, quoting W. Shakespeare, Macbeth, V, v, 27-28, 83 A.D.2d 810, 811, 442 N.Y.S.2d 11,12). See also Fletcher v. Wesley Medical Center, 585 F. Supp. 1260, 1265

(D. Kan. 1984) (einployee handbooks are not "legally insignificant sound and fury").

76. See infra notes $77-93$ and accompanying text.

77. 408 Mich. 579,292 N.W.2d 880 (1980).

78. Id. at 595, 597-98, 292 N.W.2d 883-84. The employer, Blue Cross \& Blue Shield of Michigan, "published and distributed a 260-page manual establishing elaborate procedures promising " $[t] 0$ provide for the administration of fair, consistent and reasonable correetive discipline' and 'to treat employees leaving Blue Cross in a fair and consistent manner and to release employees for just cause only." "Id. at 617, 292 N.W.2d at 893. 
rights in einployees without evidence that the parties mutually agreed that the policy statements would create contractual rights in the employee, and, hence, although the statement of policy is signed by neither party, can be unilaterally amended by the employer without notice to the employee, and contains no reference to a specific employee, his job description or compensation, and although no reference was made to the policy statement in pre-employment interviews and the employee does not learn of its existence until after his hiring. ${ }^{79}$

The court placed great importance on the fact that Blue Cross, by issuing an employee handbook, had created a situation " instimct with an obligation" "such that employees could justifiably rely on the handbook's policies. ${ }^{80}$

An impressive number of jurisdictions have followed Toussaint's reasonable expectation rationale. ${ }^{81}$ Nonetheless, Toussaint simply uses an estoppel argument, mvoking the idea of reliance, ${ }^{82}$ and fails to address fully the issue of consideration. Other progressive courts, however, liave

\section{Id. at $614-15,292 \mathrm{~N} . \mathrm{W} .2 \mathrm{~d}$ at 892 .}

80. Id. at $613,617,292$ N.W.2d at 892, 893 (quoting McCall Co. v. Wright, 133 A.D. 62, 68, 117 N.Y.S. 775, 781 (1909), affd, 198 N.Y. 143, 91 N.E. 516 (1910). A situation "instinct with an obligation" can be created even when there is no meeting of the minds; the employee is not aware of the particulars of the enployer's policies and the enployer can unilaterally amend the policies. The court wrote:

No pre-enployment negotiations need take place and the parties' minds need not meet on the subject; nor does it matter that the employee knows nothing of the particulars of the employer's policies and practices or that the employer may change them unilaterally. It is enough that the einployer clooses, presuniably in its own interest, to create an environment in which the employee believes that, whatevcr the personnel policies and practices, they are established and official at any given time, purport to be fair, and are applied consistently and uniformly to each employee. The employer has then created a situation "instinct with an obligation."

Id. at 613,292 N.W.2d at 892 (citations omitted).

The Supreme Court of Oklahoma has gone so far as to say that the publication of personnel policies "is the equivalent of constructive knowledge on the part of all employees not specifically excluded." Dangott v. ASG Indus., 558 P.2d 379, 383 (Okla. 1976).

For a more detailed analysis of Toussaint, see Casenote, Master \& Servant-Employment Contracts-The burden of establishing standards of performance as a basis for employment termination rests upon the employer: Toussaint v. Blue Cross \& Blue Shield, 59 U. DET. J. URB. L. 83 (1981); Casenote, Employment Contract-Indefinite Length-Hiring Terminable By Employer for Cause Only Without Mutuality of Obligations-For Cause Requirement Implied Where Reasonable Expectations Created By Employee Policy.Manual, 28 WAYNE L. Rev. 373 (1981).

81. See Brooks v. Trans World Airlines, Inc., 574 F. Supp. 805, 809 (D. Colo. 1983) (citing Pine River State Bank v. Mettille, 333 N.W.2d 622 (Minn. 1983); Arie v. Intertherm, Inc., 648 S.W.2d 142, 153-54 (Mo. App. 1983); Simpson v. Western Graphics Corp., 293 Or. 96, 100, 643 P.2d 1276, 1278 (1982); Hamby v. Genesco, Inc., 627 S.W.2d 373, 376 (Tenn. App. 1981); Langdon v. Saga Corp., 569 P.2d 524, 527 (Okla. Ct. App. 1976); Wagner v. Sperry Univac, Div. of Sperry Rand Corp., 458 F. Supp. 505, 520-21 (E.D. Pa. 1978), affd mem., 624 F.2d 1092 (3d Cir. 1980); Piacitelli v. Southern Utah State College, 636 P.2d 1063, 1066 (Utah 1981) (tenure denial)).

82. See Toussaint v. Blue Cross \& Blue Shield, 408 Mich. 579, 617, 292 N.W.2d 880, 893 (1980) (since einployer published and distributed a manual establishing elaborate disciplinary procedures and promising to dismiss employees for just cause only, employees "could justifiably rely on these expressions and conduct themselves accordingly"). 
made an attempt to address that issue and have rejected the idea that independent consideration-consideration other than services to be rendered-is necessary to support a contract based on employer promises as found in an employee handbook. ${ }^{83}$ Independent consideration is viewed as a rule of construction, not of substance; 84 it serves the evidentiary function of determining if the parties intended to be bound by certain terms, ${ }^{85}$ and its absence is not a bar to finding a vahd contract. Thus, the rule of additional consideration

does not preclude the parties, if they make clear their intent to do so, from agreeing that the employment will not be terminable by the employer except pursuant to their agreement, even though no consideration other than services to be performed is expected by the employer or promised by the employee. ${ }^{86}$

Similarly, the requirement of mutuality of obligation has been criticized and the need for it deeined synonymous with the need for consideration. ${ }^{87}$ According to this view, the mere performance of services is sufficient consideration to make an employee handbook part of an at-will contract, whether the handbook is viewed as a modification to a preexisting contract (as when it is given to an employee after he begins work) ${ }^{88}$ or as part of the original contract (as when an employee is given the handbook when he begins employment). ${ }^{89}$

Finally, the doctrime of employment-at-will is viewed as a rule of construction, rather than one of substance. ${ }^{90}$ The doctrime itself does not preclude the parties from proving they intended that the employment relationship could be terminated only pursuant to their agreement, even

83. E.g., Vinyard v. King, 728 F.2d 428, 432-33 (10th Cir. 1984); Brooks v. Trans World Airlines, Inc., 574 F. Supp. 805, 809-10 (D. Colo. 1983); Pugh v. See's Candies, Inc., 116 Cal. App. 3d 311, 324, 171 Cal. Rptr. 917, 924 (1981); Cleary v. American Airlines, Inc., 111 Cal. App. 3d 443, 454-56, 168 Cal. Rptr. 722, 727-30 (1980); Pine River State Bank v. Mettille, 333 N.W.2d 622, 627 (Minn. 1983); Weiner v. McGraw-Hill, Inc., 57 N.Y.2d 458, 464-65, 443 N.E.2d 441, 444-46, 457 N.Y.S.2d 193, 196-98 (1982).

84. Pugh v. See's Candies, Inc., 116 Cal. App. 3d 311, 326, 171 Cal. Rptr. 917, 925 (1981); Cleary v. American Airlines, Inc., 111 Cal. App. 3d 443, 452, 168 Cal. Rptr. 722, 727 (1980) (citing Drzewiecki v. H \& R Block, Inc., 24 Cal. App. 3d 695, 703-04, 101 Cal. Rptr. 169, 174 (1972)); Pine River State Bank v. Mettille, 333 N.W.2d 622, 629 (Minn. 1983).

85. Pugh v. See's Candies, Inc., 116 Cal. App. 3d 311, 326, 171 Cal. Rptr. 917, 925 (1981).

86. Pine River State Bank v. Mettille, 333 N.W.2d 622, 629 (Minn. 1983).

87. Weiner v. McGraw-Hill, Inc., 57 N.Y.2d 458, 463-64, 443 N.E.2d 441, 444, 457 N.Y.S.2d 193, 196 (1982); Pine River State Bank v. Mettille, 333 N.W.2d 622, 629 (Minn. 1983).

88. E.g., Pine River State Bank v. Mettille, 333 N.W.2d 622, 627-30 (Minn. 1983); Southwest Gas Corp. v. Ahmad, 99 Nev. 594, 595, 668 P.2d 261, $261-62$ (1983).

89. E.g., Leikvold v. Valley View Community Hosp., 141 Ariz. 544, 548, 688 P.2d 170, 173 (1984) (en banc); Weiner v. McGraw-Hill, Inc., 57 N.Y.2d 458, 460, 443 N.E.2d 441, 444, 457 N.Y.S.2d 193, 196-98 (1982). (1984).

90. See Leikvold v. Valley View Community Hosp،, 141 Ariz. 544, 546, 688 P.2d 170, 172 
if no consideration, other than services performed, is given..$^{91}$ The very freedom of contract argument which has long been used to justify the employment-at-will doctrine ${ }^{92}$ has been used to criticize the traditional apphication of that doctrine: "There is no reason why the at-will presumption needs to be construed as a limit on the parties' freedom of contract. If the parties choose to provide in their employment contract of an indefinite duration for provisions of job security, they should be able to do so."93 While traditional courts have effectively barred recovery by insisting that if there is no additional consideration for a handbook the at-will rule will permit discharge for any reason, progressive courts have discounted both the need for additional consideration and strict adherence to the employinent-at-will rule, viewing both as rules of construction.

\section{The Wave of the Future Through a Doctrine of the PAST: Unilateral ConTract ANAlysis of Employee HANDBOOKS}

Beyond the merits of the discussion concerning the need for consideration which has so spht American jurisdictions, there is soinething artificial about how nearly all of the traditional and progressive courts have analyzed the contractual status of employee handbooks. Although both types of courts have nearly always discussed the consideration necessary to bind an alleged agreement embodied in the provisions of the handbook, they have also nearly always neglected to discuss the agreement itself. The process of agreeinent is commonly analyzed by looking for an offer and an acceptance, ${ }^{94}$ yet, the employee handbook cases fail to pay even perfunctory attention to these most basic tools of contractual analysis.

Analytically, it is important in employee handbook cases to study the agreement process for two reasons. First, handbook language may not be specific enough to constitute an offer. If a court fails to examine the specificity of handbook language in order to ensure that strict promissory language exists, it may give a plaintiff unwarranted relief. Failure to examine closely the provisions of an employee handbook is really a failure to determine if a plamtiff's rehance was justifiable. It may be a simple proposition, but by explicitly addressing the question of whether a

91. Pine River State Bank v. Mettille, 333 N.W.2d 622, 628-29 (Minn. 1983).

92. See supra notes $12-13$ and accompanying text.

93. Pine River State Bank v. Mettille, 333 N.W.2d 622, 628 (Minn. 1983); see also Leikvold v. Valley View Comunity Hosp., 141 Ariz., 544, 546, 688 P.2d 170, 173 (1984) (the employment-at-will rule is not a limit on the parties' freedom to contract.).

94. E. FARNSWORTH, supra note $27, \S 3.3$ (outlining traditional offer and acceptance analysis). 
handbook's provisions are sufficiently specific to show an intent by the employer to make an offer, a progressive court, which will find the consideration requirement easily inet, may be less likely to give effect to ostensible promises..$^{95}$

Second, an offer must be commumicated and accepted. In the einployee handbook context, this means that before a plaintiff can find rehef in contract, he must show that the handbook was not solely an internal docuinent for management but that it was published for general distribution to employees-communication of the offer-and that he was generally aware of the policies and continued to work for the einployeracceptance. ${ }^{96}$ In this way, a discliarged employee who was not even generally aware that his employer had published termination procedures in a handbook until after he was discharged will not find rehef because there was no commumication of the offer, and lience no acceptance and reliance.

In short, courts dealing with einployee liandbooks in an at-will enployinent situation sliould apply an analysis found in the common law of contracts-unilateral contract theory. Under that theory, when only one of two parties to a contract lias inade a promise, the contract is unilateral; a bilateral contract, by contrast, is one in which both parties liave inade promises. ${ }^{97}$ In bilateral contracts, botli parties inust be bound or there is no contract. Unilateral contracts have no sucli requirement. 98 Thus, unilateral contracts are an exception to the doctrine of "inutuality of obligation." For exainple, if an employer offers his at-will einployees a bonus if they remain on the job for a specified period of time and the employees continue to work through that specified period, they will be

95. See infra note 108 and accompanying text.

96. See, e.g., Southwest Gas Corp. v. Ahmad, 99 Nev. 594, 595-601, 668 P.2d 261, 262-65 (1983) (Steffen, J., dissenting) (to coustitute an offer, handbook must be more than "current directory" of company policies, and acceptance requires employee to be aware of offer).

97. J. Calamari \& J. Perillo, supra note 27, § 1-10. The typical teaching example of the difference between a unilateral and bilateral contract involves the Brooklyn Bridge:

If A says to B, "If you walk across Brooklyn Bridge, I promise to pay you ten dollars," A has made a promise but he has not asked $B$ for a return promise. He has requested $B$ to perform an act, not a commitment to do the act. A has thus made an offer to a unilateral contract which arises when and if B performs the act called for. If $A$ had said to B, "If you promise to walk across Brooklyn Bridge, I promise to pay you ten dollars," his offer requests $B$ to make a commitment to walk the bridge. A bilateral contract arises when the requisite return promise is made by $B$.

Id.

Whether or not the offeree intended to accept a unilateral offer is miportant because performance of the requested act is not necessarily in response to the offer. Id. $\S 2-16$. The Restatement of Contracts (Second) provides that an intent to accept is presumed, in the absence of words or conduct to the contrary, when the act is done with knowledge of the offer. RESTATEMENT (SECOND) of CONTRACTS $\S 53$, comment c (1981).

98. See J. Calamari \& J. Perillo, supra note 27, § 4-15. 
entitled to the bonus. Continuing to work is consideration. Even though the employees were not requested to nor were in any way obligated to continue working-that is, there was no "inutuality of obligation"-the einployer is bound to his promise. 99

While the dichotomy between unilateral and bilateral analysis found in the common law plays a less inportant role in contemporary contract analysis, ${ }^{100}$ it is nonetheless appropriate and useful in the employee handbook context. Unilateral contract theory may not be appropriate for analyzing "complex negotiations typical of substantial transactions," 101 but the typical employee handbook case, like the employee bonus case, is a simple enough transaction that unilateral contract analysis can adequately describe the process of agreement that takes place between an einployer and an einployee.

Unilateral contract analysis, coinbined with the progressive court approach to consideration, is particularly useful in the employee handbook context because it can effectively balance the competing interests of employer and employee. The reasonable expectations of both parties will be protected. Under unilateral contract analysis, the einployer, by using certain handbook language, ${ }^{102}$ will still be able to change company policy as his business environment and needs change, while benefiting from a loyal and cooperative work force that results froin the establishment of stable coinpany pohicies. ${ }^{103}$ At the same time, employees who are aware of company policy and who naturally expect to benefit from certain provisions of a handbook will be able to do so, as long as the company policy reinains in effect. ${ }^{104}$ In that way, for example, employees who are promised that certain grievance and termination procedures will be followed

99. Id. Another example is that of the option contract (or irrevocable offer) that contains a promise to sell or buy in exchange for a price. The offeror must perform at the election of the offeree who is in no way obliged to take the option. Botli parties have provided consideration and that is enough to make a contract; no mutuality of obligation is necessary. Id.

100. E. FARNSWORTH, supra note $27, \S 3.4$.

101. Id. $\S 3.5$.

102. See Pine River State Bank v. Mettille, 333 N.W.2d 622, 627 (Minn. 1983) ("Language in the liandbook itself may reserve discretion to the employer in certain matters or reserve the right to amend or modify the handbook provisions.").

103. In establishing personnel policies, "the employer secures an orderly, cooperative and loyal work foree, and the employee the peace of mind associated witl job security and the conviction that he will be treated fairly." Toussaint v. Blue Cross \& Blue Shield, 408 Mich. 579, 613, 292 N.IV.2d 880,892 (1980).

104. Of course, the employee will be bound by the terms of the handbook in that he or she must satisfy any necessary conditions precedent attaclied to particular benefits found in the handbook. See Sweet v. Stormont Vail Regional Medical Center, 231 Kan. 604, 606, 612, 647 P.2d 1274, 1277, 1281 (1982) ("In order to be entitled to payment for accrued vaeation time upon termination of employment, the claimant was required to give [her employer] two weeks' notice of her intent to quit, [as required by the handbook]."). 
cannot be properly discharged, under their employment-at-will contracts, without having first been given the benefit of the procedures promised in the handbook.

Moreover, unilateral contract analysis will not seriously threaten the existence of the employment-at-will doctrine, an attractive prospect for the so-called "traditional" courts. Employees hired at no fixed term, absent unlawful discrimination, a judicially inposed good cause requirement or statutory protection, can still be dismissed for any reason, good or bad, as long as the provisions found in company handbooks are followed.

Unilateral contract analysis has recently been applied to an employee handbook case by the Supreme Court of Minnesota in Pine River State Bank v. Mettille. ${ }^{105}$ At the beginning of its inquiry into the contractual status of an einployee handbook distributed after tlie plaintiff was hired, the court recognized the miportance of not only examining consideration, but also the agreement process itself: "Whetlier a handbook can become part of tlie employment contract raises such issues of contract formation as offer and acceptance and consideration." 106 The court stated that just as a promise of employment on particular terms of employment of unspecified duration may be a binding unilateral contract, if $m$ the form of an offer and accepted by the einployee, so may handbook language create a bimding unilateral contract. ${ }^{107}$ If the liandbook's language is sufficiently specific, it may create an offer. ${ }^{108}$ In order for the offer to be accepted, it must be communicated to tlie employee by

105. 333 N.W.2d 622 (Minn. 1983). In Pine River, the Pine River State Bank sued a former einployee, Mettille, on two notes on which he was in default. Mettille counterclaimed, alleging that the bank had breached his enployment contract, as subsequently inodified by an employee handbook. Id. at 625 .

Mettille's enployment contract was entirely oral and was not for a specific term; it was at will. Id. at 624. About seven inonths after Mettille was hired as a loan officer, the bank distributed a printed "Einployee Handbook" that contained several job security provisions. Id. Of particular importance was a section entitled "Disciplinary Policy," that provided for a three-stage disciplinary procedure. The first and second "offenses" would receive reprimands, and thereafter an einployee would be suspended or discharged. Discharge was only "for an einployee whose conduct does not inprove as a result of the previous action taken." Id. at 626. The section concluded with the sentence: "In no instance will a person be discharged from einployment without a review of the facts by the Executive Officer." Id.

Following an unannounced examination of the bank and an imternal investigation that revealed Mettille was responsible for $\mathbf{5 7}$ of the $\mathbf{5 8}$ "serious" technical exceptions discovered, Mettille was fired by the president of the bank. The disciplinary procedures outlined in the handbook were not followed. Id. at 624-25.

106. Id. at 625 .

107. Id. at 626-27.

108. Id. at 626 . But, "[a]n employer's general statements of policy are no more than that and do not ineet the contractual requirements for an offer." Id. 
dissemination of the handbook to the employee. 109

After it has been determined that an offer is found in a handbook's language and that the offer was cominumicated to the employee, the next step in the analysis, according to the court, is to determine if there was an acceptance of the offer and if consideration has been furnished, making the contract enforceable. ${ }^{110}$ Analogizing to a case in which an employer's promise of a bonus has been held to be an enforceable unilateral contract, ${ }^{111}$ the court held that an employee's retaiming his employnent constitutes acceptance of the handbook's offer and continuing to work supplies the necessary consideration. The court wrote:

In the case of unilateral contracts for employment, where an at-will employee retains employment with knowledge of new or changed conditions, the new or changed conditions may become a contractual obligation. In this manner, an original employment contract may be modified or replaced by a subsequent umiateral contract. The employee's retention of employment constitutes acceptance of the offer of a unilateral contract; by contimuing to stay on the job, although free to leave, the employee supplies the necessary consideration for the offer. ${ }^{112}$

The court then concluded "that personnel handbook provisions, if they meet the requirements for formation of a unilateral contract, may beconie enforceable as part of the original employment contract."113

After examining the reasons traditionally given for not enforcing job termination restrictions im an employment-at-will contract, the Pine River court adopted the progressive treatment of consideration and mutuality of obligation. ${ }^{114}$ The imdefiniteness inherent in an employnient-atwill contract, according to the court, does not by itself "preclude handbook provisions on job security from being enforceable, whether they are proffered at the time of the original hiring or later, when the parties have agreed to be bound thereby."115 Thus, although Pine River dealt with a newly introduced handbook modifymg the preexisting einploynient-at-

109. Id.

110. Id. at 626-27.

111. Id. at 627. The court cited Hartung v.Billmeier, 243 Minn. 148, 155, 66 N.W.2d 784, 790 (1954), where it had held that an employer's promise of a bonus made after the employee started working was enforceable.

112. Pine River, 333 N.W.2d at 627 . It is possible to characterize the unilateral contract in such a way that the einployer will not be held to have breached the contract if he modifies or replaces the handbook after the enployee has already accepted the unilateral offer by commeneing work or continuing to work. One possible formulation "is to characterize the einployer's promise soinething like this: 'I promise I will not dismiss you . . . without exhausting specified procedures . . . unless I change this policy before you are discharged." " H. PERRITT, supra note 2, at 150 (citation onitted).

113. Id.

114. Id. at 628-30. See also supra notes 73-93 and accompanying text.

115. Pine River, 333 N.W.2d at $629-30$ (emphasis added). 
will contract, the court made it clear that a handbook offered at the time of hiring can also be an enforceable unilateral contract. ${ }^{116}$

Fimally, the Pine River court recognized that treatimg employee handbooks as unilateral contracts does not unduly circumscribe the employer's discretion. An employer can still limit transactional costs of hiring employees by making a unilateral offer $\mathrm{m}$ an employee handbook rather than making separate contracts with each individual employee and by changing policies as it sees fit: "Unilateral contract inodification of the employment contract may be a repetitive process. Language in the handbook itself may reserve discretion to the employer in certam matters or reserve the riglit to anend or nodify the handbook provisions."117

116. The court then applied the principles of unilateral contract theory and the progressive treatment of consideration to the facts before it. The court began by holding that the liandbook language in the section entitled "Job Security," id. at $626 \mathrm{n.2}$, was not specific enougl to constitute an offer; it was no more than a general statement of policy. Id. at 630. However, the court lield that the landbook section entitled "Disciplinary Policy" did "set out in definite language an offer of a unilateral contract for procedures to be followed in job termination." Id. That sectiou contained the explicit promise that if "an einployee has violated a conıany policy, the following [three step termination procedure] will apply." Id.

The offer contained in tlie section entitled "Disciplinary Policy" was communicated to all employees, including Mettille, by distribution of the handbook. Id. at 624,630 . The court found that Mettille's continued performance of his duties, despite his freedom to quit, constituted both an acceptance of the bank's offer and the necessary consideration for the offer. The bank gained the advantages of a presuniably more stable and productive work force. Id. at 630. The court concluded: "Therefore, we hold as a nuatter of law the bank breached its enıploynnent contract witlı Mettille by not affording hin the job termination procedures of its landbook, resulting in Mettille's unemployment." Id. at 631.

Anotlier application of unilateral contract analysis to an employee handbook case appears in Langdon v. Saga Corp., 569 P.2d 524, 527-28 (Okla. Ct. App. 1976) (persomrel policies extending benefits [i.e., accrued paid vacation time and certain severancc allowances] may be construed as unilateral offers which are accepted by continued performance and requirement of inutuality is inet in that no benefits can accrue under tlose policies until performance lias occurred); see also Wagner v. Sperry Univac, Div. of Sperry Rand Corp., 458 F. Supp. 505, 520 (E.D. Pa. 1978) (unilateral contract analysis reveals that the at-will enuploynent relationship is not inevitably a legal nullity), aff'd mem., 624 F.2d 1092 (3d Cir. 1980); Chinn v. Clina Nat'l Aviation Corp., 138 Cal. App. 2d 98, 99-102, 291 P.2d 91, 92-94 (1955) (eniployer's regulations constituted an offer of a unilateral contract that was accepted by enıployec when lie continued to work); Haney v. Laub, 312 A.2d 330, 332 (Del. Super. Ct. 1973) (an eniployee stock option agreenient represents an enforceable unilateral contract); Banas v. Mattlews Int'l Corp., No. 1205 Pittsburglı (Pa. Super. Ct. June 15, 1984) (available Feb. 9, 1985, on LEXIS, states library, $\mathrm{Pa}$ file) ("Conceptually in the at-will eniploynient context, an employee nianual is best viewed as part of an eniployer's unilateral offer of eniploynient.") (citations omitted); Amicone v. Kennecott Copper Corp., 19 Utah 2d 297, 300, 431 P.2d 130, 132 (1967) ("[T]he retirement plan is in the nature of a unilateral contract."); Hercules Powder Co. v. Brookfield, 189 Va. 531, 540-41, 53 S.E.2d 804, 808 (1949) (1nen10 promising severance pay distributed by the employer to the employees was offer wlich was accepted by the enuployee by performing lis services).

117. Pine River, 333 N.W.2d at 627.

For a view that is critical of the Pine River decision, see Case Note, At-Will EmploymentContractual Limitation of an Employer's Right to Terminate: Pine River State Bank v. Mettille, 333 N.W.2d 622 (Minn. 1983), 7 HaMLine L. REv. 463 (1984). The autlior of that case note considers 
Other courts have recognized that employers are free to exclude or modify the benefits found in an employee handbook to the extent that accrued benefits-e.g., vacation and severance pay-are not affected; the exclusion or modification of accrued benefits must be done prospectively. ${ }^{118}$ And, of course, the einployer is free not to make an offer at all simply by not issumg a handbook or making it clear and conspicuous that the handbook is not part of the employinent-at-will contract. ${ }^{119}$ In this way, an employer will create no reasonable expectations of perform-

the court's approach in Pine River to be "unorthodox" and asserts that the "principal difficulty with the court's analysis is . . . that a contract was deeined to exist although neither party was aware of it." Id. at 476-77. The author does not believe that the distribution of a handbook and the retention of a job after accepting a handbook can be an objective manifestation of a contract. Id. at 477. One inust wonder if the author believes that employers issue handbooks as a gratuitous source of inforination with no expectation of receiving any benefit in the form of employee loyalty and the like, and that employees read handbooks with the clear understanding that all of the employer promises found in handbooks are non-bimding.

In rejecting the analysis adopted by the Pine River court, the case note argues that a better way to serve the interests of both employer and employee is to infer a covenant not to discharge employees for refusing to violate public policy, as expressed in a statute or constitution. Id. at 481-82. Such a proposal, however, is wholly inadequate to protect the interests of the plaintiff in Pine River or the interests of plaintiffs in typical employee handbook cases. Pine River sunply is not a retaliatory discharge case. See Pine River, 333 N.W.2d at 630 ("We are not dealing with a discharge that is retaliatory, in bad faith or abusive."). The plaintiff in Pine River complained that he was denied the benefit of disciplinary procedures found in the handbook; he did not complain, and could not successfully have complained, that he was dismissed for refusing to violate a constitutionally or statutorily expressed public policy. What is more, it is inconceivable that any plaintiff in the typical employee handbook case, where employer promises are allegedly broken, will find relief by asserting the public policy exception.

For a general discussion of the public policy exception, see DeGiuseppe, supra note 1 at 30-34, 36-39; supra note 20 and accompanying text.

118. See, e.g., Langdon v. Saga Corp., 569 P.2d 524, 527-28 (Okla. Ct. App. 1976) ("employer remains free to inodify such policies prospectively and to the extent there is no accrual").

119. See, e.g., Fletcher v. Wesley Medical Center, 585 F. Supp. 1260, 1264 (D. Kan. 1984) (dictum) ("appropriate express disclaimers [in employee handbook] could make it obvious that employer was not giving up its right to fire at will"); Leikvold v. Valley View Community Hosp., — Ariz. 一, 688 P.2d 170, 174 (1984) (en banc) (dictun) ("Einployers are certainly free to issue no personnel manual at all or to issue a personnel inanual that clearly and conspicuously tells their employees that the inanual is not part of the employinent contract."). However, oral assurances by an einployer that an employee will receive the benefit of the handbook's provisions may render the handbook's disclainer ineffective. A court addressing such a situation wrote:

[T]o the extent that the oral assuranees of severance pay conflicted with the manual's disclaimers, or induced [employees] to disregard their significanee, we hold that such representations will negate the effect of disclaimers which are intended to absolve the employer from liability for unilateral alterations of or deviations from policies presented in the written inanual or similar employer writings.

Helle v. Landmark, Inc., 15 Ohio App. 3d 1, — 472 N.E.2d 765, 775 (1984) (citation omitted). It should be noted that the court in Helle found that because the plaintiffs were told that the plant would be closed within a year, "their enployment relationship ccased to be one terminable 'at-will" and, instead, bccome one for a reasonably specific or reasonably determinable period." Id. at —, 472 N.E.2d at - Whether an enployment contract is at-will or for a definite term should be of no consequence to the finding that oral promises can render a liandbook's disclaimer ineffective. 
ance, but neither will he be able to induce a inore stable or efficient work force. ${ }^{120}$

In summary, under unilateral contract analysis, the promises and benefits found in employee handbooks will becoine part of an at-will employinent contract if the following conditions are inet: (1) the promises found in the handbook are specific enough to constitute an offer; 121 (2) the offer is communicated by the distribution of the handbook to the employee; 122 (3) the employee who is generally aware of the coinpany policy, ${ }^{123}$ accepts the offer found in the handbook by commencing work or continuing to work; ${ }^{124}$ (4) by thus commencing work or continuing to work while retaining the freedom to quit, the employee provides consideration sufficient to make a unilateral offer binding. 125

\section{Conclusion}

Employers do not issue employee handbooks simply out of altruistic impulses; they expect to receive some benefit. Likewise, employees do not read and coinply with einployee handbooks simply because they have warm feelings about their einployer; they, too, expect to receive soine benefit. Traditional courts, with an unduly restrictive view of the einployinent-at-will doctrime, have failed to understand this. Many progressive courts, with a perfunctory use of contract analysis, have failed to

120. Toussaint v. Blue Cross \& Blue Shield, 408 Mich. 579, 613, 618, 292 N.W.2d 880, 892, 89495 (1980).

121. See, eg., Ellis v. El Paso Natural Gas Co., 115 L.R.R.M. (BNA) 2995, 2997 (D.N.M. 1983) (the provisions of a handbook must be definite in order to constitute a contract), aff'd, No. 84-1095 (10th Cir. Feb. 11, 1985) (available Feb. 25, 1985, on LEXIS, Genfed library, Cir file); Lieber v. Union Carbide Corp., Nuclear Div., 577 F. Supp. 562, 564 (E.D. Tenn. 1983) (relatively general statenients in a handbook do not create contractual riglits); Borden v. Skinner Chuck Co., 21 Conn. Supp. 184, 191-92, 150 A.2d 607, 610-11 (Conn. Super. Ct. 1958) (policy stating that it was custonary to give bonuses was not an offer).

122. Pine River State Bank v. Mettille, 333 N.W.2d 622, 626, 631 (Minn. 1983). For the offer to be capable of acceptance, the eniployce need not have read the handbook itself prior to or during lis employment; the employee nuay learn of the benefit in a number of ways, such as talking to fellow einployees or reading company notices. DeGiuseppe, supra note 1, at 51-52.

123. The employee does not have to know the particulars of the employer's policies. Toussaint v. Blue Cross \& Blue Slield, 408 Mich. 579, 613, 292 N.W.2d 880, 892 (1980).

124. Pine River State Bank v. Mettille, 333 N.W.2d 622, 627, 629-30 (Minn. 1983).

125. See Pine River, 333 N.W.2d at $627,629-30$. Any concern with the judicial administrability of applying unilateral contract analysis to eniployee handbook cases is satisfactorily addressed by the fact that the pleading in such cases will be simple. The plaintiff will have to plead that the pronises found in the liandbook were specific enough to constitute an offer, that he was generally aware of the handbook pronises, and that lie thus accepted the unilateral offer and provided consideration by comniencing work or continuing to work. Similarly, the eniployer can plead that the promises were too vague to constitute an offer, that the employee was conipletely ignorant of the eniployer promises, or tlat the handbook stated clearly that the employer pronises were not a part of the atwill eniployee's contract. For a general discussion of pleading in an employce disnissal case, see H. PERRITT, supra note 2, §§ 4.21-.22. 
explain this. All courts are urged to apply unilateral contract analysis to employee handbook cases. In this way, employer discretion will be maintained and employees relying on einployer policy will be protected.

Richard Harrison Winters 